\title{
Preventing further climate change: A call to individual action through a decrease in meat consumption
}

\author{
T.D. Raphaely and D. Marinova \\ Curtin University Sustainability and Policy Institute (CUSP), Perth, Australia \\ Email: sustainablyspeaking@westnet.com.au
}

\begin{abstract}
As the threats and realities of global warming, and the concomitant urgency of decarbonising cities and regions become increasingly apparent, academics, governments, NGOs, local and international think-tanks and policy initiators, continue to concentrate on initiatives largely aimed at reducing fossil fuels (specifically transport and energy use) and increasing development of economies based on renewable energies. Yet, to date, the progress has been slow. Despite being one of the greatest causes of anthropogenic greenhouse gases, meat production and consumption seldom get attention. The negative effects of the ever-increasing livestock sector are felt across a wide range of areas and much scientific evidence is left unnoticed. This includes serious contributions to environmental concerns, including climate change, water and air pollution, deforestation, land degradation, decreases in habitat and biodiversity as well as direct negative social impacts such as direct responsibility for deteriorating human physical and mental health, global inequality and world hunger, and non-sensitivity to factory farming and slaughter.

This paper uses extrapolation and generalisation in assessing the impact of meat consumption on the globe, including putting it into perspective in comparison to other commonly acknowledged and accepted factors, such as transport. It also highlights some stumbling blocks, vested interests and existing attitudes that make the meat problem not only persist but also expand over the developing world.

The study suggests that current decarbonising focuses are disempowering and as a result, to date, insufficiently effective. It proposes a new ethics model of increasing vegetarianism to empower individuals to make a meaningful and significant, personal contribution to climate change mitigation. It is easy and does not require significant policy, institutional or industrial changes. If adopted and implemented, such an ethics model will ensure that, individually and collectively we have the power not only to address and resolve a currently overwhelming number of social and environmental threats, but essentially, to change the current global warming trajectory and return the planet's climate patterns to safer levels.
\end{abstract}

Keywords: Sustainability, vegetarianism, empowerment, decarbonising 


\section{INTRODUCTION}

The affluent middle to high-income class in the developed world, living in relative privilege, with an abundance of support systems, life options and choices, has so far largely been protected from the early onset impacts of climate change. Yet the world is in crisis: people are sweltering, freezing, starving, thirsting and drowning. Climate change promises to cause increasingly violent, chaotic, extreme weather events every year and climate disruption tragedies will become more commonplace (Parry et al., 2007). Today's children will grow up in a world of life-threatening weather: violent storms, depression and mental health conditions, breakdown of families and communities (Climate Institute, 2011), unexpected droughts, expanding deserts and food scarcity (Goodland, 2010a). Shifting to alternatives to fossil fuel energy is most commonly seen as the solution but although crucial, changing to renewable energies is not fast enough. Ample scientific evidence (e.g. Corvalan et al., 2005; IPCC, 2007; CBD, 2010) shows that carbon dioxide $\left(\mathrm{CO}_{2}\right)$ emissions continue to grow and if this trend continues for another 10 years, it will be practically impossible to return to atmospheric conditions beneath the tipping point for catastrophic events (Schneider, 2009). The global commitment to sustainable development has thus far failed to challenge the established geopolitical systems and sources of power that globally preside over the carbon energy-intensive growth that continues to fuel climate change (Stallworthy, 2009). People living in poorest countries are more vulnerable and will suffer earliest and most even though they have contributed least to the causes (Stern, 2006; Dixon, 2010).

Nationally and locally, climate change mitigation programs focus on reducing individual and household energy and transport use (Gilligan et al., 2010; including initiatives such as Days of Change, Travel Smart, and Living Smart). The value of this in terms of limiting greenhouse gas (GHG) emissions is constrained not by the will of the participating individuals but by the infrastructural limitations of the places they inhabit. Even if every individual made such changes in their personal lives, the collective impact would be worthwhile but insufficient to effect the necessary reductions in GHGs. With no apparent competent global will, individuals are feeling disempowered, helpless and hopeless (Climate Institute, 2011).

Yet all is by no means lost. When leaders and nations fail to agree, voluntary individual action can make a significant difference - in this case, producing rapid GHG reductions at no extra cost, without politically controversial local, national or global government regulation and without dependence on the will or actions of those seemingly more powerful (Goodland and Anhang, 2009; Gilligan et al., 2010; Goodland, 2010a, 2010b). Simply put, decreasing individual meat consumption in western countries has the power to arrest the seemingly inexorable march of climate change with all its tragic consequences and costs, to change the world as we might come to know it, to bring about an end to human, animal and planetary suffering and to create a compassionate and connected world. Meat consumption is one of the gravest threats to the long-term sustainability of humankind (Compassion in World Farming, 2004), and eating less meat is the most powerful and valuable change anyone can make to prevent further climate change (FAO, 2006; Goodland, 2010b). The aim of this paper is twofold: to analyse the impact increasing meat consumption has on the ecology and humans, and to argue for a new individual paradigm of empowerment that can stop destruction.

\section{IGNORED TRUTHS ABOUT THE IMPACTS OF MEAT}

Contributing to such a critical, urgent solution doesn't require a complete end to all meat consumption but rather a substantial decrease, particularly for the urban middle class. Any individually decided action is the one that, through seeking better alternatives, maximises personal wellbeing and the overall wellbeing of the greatest number of people while ensuring human and interspecies justice and equality (Shaw, 1999). This, coupled with a belief in the intrinsic good of ordinary individuals, leads to an understanding that lack of awareness rather than lack of compassion or will, is responsible for any harmful or destructive action.

The approach we use to describe the current meat consumption and associated practices is a simple but powerful one - it is based on ethics as well as generalisation and extrapolation in order to put into perspective the consequences of exorbitant meat consumption. We draw on publically available data and estimates from developed countries and international organisations, to present the current situation and trends of livestock's impact. Unless one believes that humans are all individually motivated only by gluttony and greed, it defies logic that, rather than contributing to the creation of a world of self-sufficiency, equity, harmony, compassion and plenty, an aware individual will consciously choose complicity in the most socially and environmentally destructive habit of our time. However most individuals do not know the truth as it is often deliberately concealed through vested political and economic interests. The sections below shed some light on this and call for an individual empowerment process that through awareness and the vision of better, alternative futures, may reduce the ecological footprint of humanity including decarbonising the world. 
The livestock-climate connection: In 2001, the Australian Greenhouse Office reported the Australian livestock subsector was the nation's largest source of agricultural GHG contributing over 13\% of Australia's total national emissions (Hegarty, 2001). The FAO (2006) calculated global meat supply emissions to be $18 \%$ of total annual worldwide GHG emissions in 2006. Goodland and Anhang (2009) argued that, despite being recognised as the biggest contributor to global GHG emissions, the climate impact of the global livestock sector had been vastly underestimated and actually accounts for at least $51 \%$ of all annual, worldwide anthropogenic GHG emissions. Given these figures, replacing livestock products with alternative plant-based foods offers a more rapid impact on reducing GHG emissions and their atmospheric concentrations than any actions to replace fossil fuels with renewable energy (Goodland and Anhang, 2009). Yet, despite the massive opportunity a reduction in meat consumption offers, it is largely ignored. A $25 \%$ reduction in global consumption of livestock products worldwide would yield a $12.5 \%$ reduction in global anthropogenic GHG emissions (Goodland, 2010a) - as much reduction as delegates failed to negotiate in 2009 in Copenhagen. As the West is responsible for significantly more meat consumption than people in the developing world, much of the onus and opportunity for personal reduction exists where the bulk of the $\mathrm{CO}_{2}$ was created. For example an average Australian eats about $123 \mathrm{~kg}$ of meat a year (ChartsBin, n.d.) or about $337 \mathrm{~g}$ a day. According to DEFRA (n.d.), $1 \mathrm{~kg}$ of beef produces about $35 \mathrm{~kg}$ of $\mathrm{CO}_{2} \mathrm{e}$ emissions. If every Australian gave up meat for just one day a week, each person would decrease their individual emissions by $613 \mathrm{~kg}$ of $\mathrm{CO}_{2} \mathrm{e}$ per annum, the equivalent to driving $3066 \mathrm{~km}$ less a year in an average mid-size car.

Water use and pollution: The livestock sector is a key contributor to global water use and depletion and the largest sectoral source of water pollution (FAO, 2006). Livestock waste has also been implicated in massive fish kills and outbreaks of diseases. Soil compaction, resulting in reduced infiltration, degraded watercourse banks, drying up of floodplains and lowering water tables are also directly attributable to livestock farming practices (FAO, 2006). As more and more water is diverted to raising meat animals instead of producing crops for direct consumption, millions of wells are drying up (Monday, 1999). To produce I $\mathrm{kg}$ of feedlot beef requires about $100000 \mathrm{l}$ of water (Millstone and Lang, 2008). At a household level, Australians use 220 1 of water per person per day (ABS, 2009). Hence $1 \mathrm{~kg}$ of beef uses 455 days and a year's beef supply (123 $\mathrm{kg}$ ) uses about 153 years of individual water consumption in Australia.

Deforestation: Increasing meat demand is the biggest force in the expansion of agriculture and agriculture is the world's biggest cause of deforestation (Monday, 1999). Seventy per cent of previous Amazon forest is now cattle pasture and feed crops cover a large part of the remainder (FAO, 2006). Forests, whilst confined to countries, are essential for the survival of the global population.

Land use and degradation: The livestock sector is the single largest anthropogenic user of land. At least $26 \%$ of the world's ice-free surface is occupied by grazing, $33 \%$ of all arable land is dedicated to feed crop production and in all, livestock production accounts for $70 \%$ of all agricultural land use and use of $30 \%$ of the land surface of the planet (FAO, 2006). The ecological impacts of such land use are extremely costly and at current consumption levels, the human population is already at earth's carrying capacity. With predicted livestock and human population growth, it will not be possible to provide enough food to sustain humanity.

Biodiversity: Unprecedented threats to biodiversity are presently constant or increasing in intensity and species losses 500 times higher than ever before are resulting in decreases in food, fibre, medicines, fresh water, pollination of crops, filtration of pollutants, and protection from natural disasters (CBD, 2010). Thirty per cent of the earth's land surface now used by livestock was recently habitat for wildlife and as the major driver of deforestation, land degradation, pollution, climate change, overfishing, sedimentation of coastal areas and facilitation of invasion by alien species, the livestock sector is the leading player in the reduction of biodiversity. Resource conflicts with pastoralists further threaten species of wild predators and most of the world's threatened species are suffering habitat loss where livestock is a factor (FAO, 2006).

Diet and health: Globalisation, emulation, harmonisation of food standards, retailer consortium domination, USA subsidies, advertising and the belief that the American diet is the best has led to a rapid world-wide adoption of "western-style" diets (Campbell and Campbell, 2006). This global nutrition transition towards diets of more meat and diary, less complex carbohydrates and reduced fruit and vegetable intakes is further encouraged by rapid urbanisation. However, these increasingly dominating food trends result from tensions between the goals of trade and industry facilitation and the national and international protection of public health (Dixon et al., 2007). The meat industry has been able to wield considerable power and influence over government policies (Simon, n.d). Despite conclusive evidence of the harmful health implications of excessive meat consumption and the benefits of a plant-based diet (Campbell and Campbell, 2006; Stone 2011) people continue to consume large amounts of meat. Obesity, hypertension, diabetes, heart disease, strokes, cancer, rheumatoid arthritis, multiple sclerosis, lupus, gallstones, atherosclerosis, verticulitis, osteoporosis, immune system disorders, allergies and asthma are just some of the diseases that annually main 
and kill millions of people as a direct result of western nutrition (Stone, 2011; Campbell and Campbell, 2011; Popkin, 2001 and 2009). Children have a 60\% increased risk of developing leukaemia if they consume meat products such as ham, sausages and hamburgers (Appleby et al., 1999). In the US about 3 million pounds of antibiotics are annually given to people and about 24.6 million pounds are fed non-therapeutically to farmed animals (Safran Foer, 2009) resulting in drug resistance in humans.

Ways of the west are not best: Throughout the developing world, people climbing out of poverty are shifting from a traditional diet of grains, vegetable pulses, roots and tubers to a western diet high in meat consumption (see Figures 2 and 3) resulting in non-communicable nutrition-related diseases overtaking

Figure 2. Per capita meat production, 2009
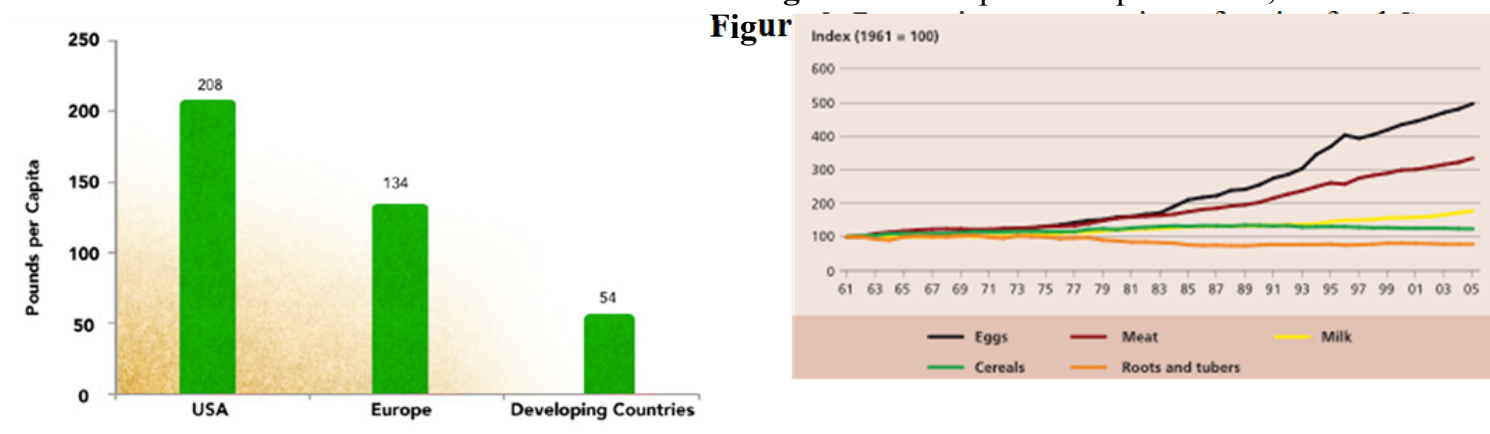

Hamerschlag, 2011. *Fish not included

items,

1961-2005. Source: FAO, 2009a.

communicable disease (Stamoulis et al., 2004). There is no point combating diseases of poverty in ways that cause diseases of affluence, such as obesity, cardio-vascular problems, cancer, type-2 diabetes and strokes (Hamerschlag, 2011). Developing countries urgently need to reaffirm their own traditional diets to forego the western experience of very expensive morbidity and mortality associated with meat-rich diets (Hamerschlag, 2011). Hopefully also the West will learn that traditional, non-western ways can sometimes be better.

Global inequality and hunger: Global hunger continues to rise (Sutcliffe, 2007) yet rich western countries continue to feed grains to animals that might instead feed people (Sere cited in Goodland, 2010b: 2). In 2008/2009 approximately 2.27 billion tonnes of cereals were produced globally (FAO, 2009), about one third of which was used to feed livestock (FAO, 2006) while nearly a billion humans suffer in hunger (FAO, 2009). By 2050 there will be another 3 billion people on the planet (US Census Bureau, 2011), so 4 billion more people to feedd. The average human needs $180 \mathrm{~kg}$ of grain per year to survive (Millstone and Lang, 2008). Thus if the grain currently used to feed livestock were reallocated to people, there could be an immediate end to world hunger and food security into the foreseeable future without any additional requirements. Clearly livestock competes for crops and detracts from the total food supply.

Factory farming and slaughter: This is the hardest aspect of the livestock sector to describe as it moves away from the science of measured impacts requiring instead discussions about sentient creatures capable of experiencing terror, fear, loss, pain, playfulness and joy, being turned into faceless production units in the name of profit and large scale efficiencies. This industrialisation of life has resulted in an unimaginable scale of suffering and misery currently affecting 60 billion animals a year (10 animals for every person alive!). The food industry, which turns living animals into what it euphemistically calls animal and animal by-products, dwarfs all other ethical concerns (Coetzee, 2007). Any video on how meat is produced turns into a horror film but the business model of factory farming depends on consumers not seeing this. Moreover the industry significantly influences academic research, agricultural policy, government regulation and enforcement (Saffron Foer, 2009). Yet the abuse of animals is a crime of stupefying proportions (Coetzee, 1999) and if we have the courage to start acting from our hearts "there is no limit to the extent to which we can think ourselves into the being of another" (Coetzee, 1999: 120), recognise their misery and understand that there can be no moral justification for not counting any form of suffering equally with the suffering of other beings or species (Singer, 1990). Certainly as far as sustainability is concerned, compassion to the suffering of other sentient beings is better than indifference (Singer and Mason, 2006).

A shift in our meat preferences can dramatically change all of the above negative impacts.

\section{WHAT IS NEEDED}

In order for individuals to understand their personal power to prevent ongoing, increasing climate change, a shift from the old to a new paradigm is necessary. Table 1 depicts elements of this change and proposes a 
new ethics model of increasing vegetarianism to empower individuals to make a meaningful and significant, personal contribution to climate change mitigation.

Table 1. Old and new individual paradigm

\begin{tabular}{|c|c|}
\hline Old individual paradigm & New individual paradigm \\
\hline Meat is an important part of a healthy diet & $\begin{array}{l}\text { Meat is not an essential part of a healthy diet and eating meat can be } \\
\text { detrimental to health }\end{array}$ \\
\hline $\begin{array}{l}\text { Public funds should rightly be directed to encourage people } \\
\text { to eat animal products and in so doing to continue to } \\
\text { promote the livestock industry and those associated with it } \\
\text { such as the big fast-food meat suppliers }\end{array}$ & $\begin{array}{l}\text { Public funds must be directed to encourage people to eat more plant } \\
\text { based protein sources and in so doing promote foods that have a } \\
\text { lower environmental impact, are more efficient in resource use, } \\
\text { healthier and more equitable }\end{array}$ \\
\hline $\begin{array}{l}\text { Don't challenge and question the food industry that tells us } \\
\text { we need meat. It all makes good economic sense. }\end{array}$ & $\begin{array}{l}\text { Challenge, question and stand up to the institutions and systems that } \\
\text { tell us we need meat. It's time for good environmental and social } \\
\text { sense to prevail, economic benefits will follow. }\end{array}$ \\
\hline $\begin{array}{l}\text { Choose not to see or know about the environmental, social, } \\
\text { economic or animal welfare considerations of factory } \\
\text { farming }\end{array}$ & $\begin{array}{l}\text { Choose to be completely aware of the environmental, social, } \\
\text { economic or animal welfare considerations of factory farming }\end{array}$ \\
\hline Westernisation is best where nutrition is concerned & Many traditional eating habits are nutritionally better \\
\hline $\begin{array}{l}\text { Progress includes changes to the nutritional ways of the } \\
\text { west }\end{array}$ & $\begin{array}{l}\text { Progress does not necessarily require giving up things that have } \\
\text { sustained human population in the past }\end{array}$ \\
\hline $\begin{array}{l}\text { Abating climate change is about national and global ways of } \\
\text { living, being, doing and creating and as such we must follow } \\
\text { our leaders }\end{array}$ & $\begin{array}{l}\text { Abating climate change is about an individual way of living, being, } \\
\text { doing and creating and as such, we must respond as aware, } \\
\text { empowered and active individuals }\end{array}$ \\
\hline $\begin{array}{l}\text { There is a limit to the expansion and realisation of } \\
\text { individual potential expressed by ordinary people and a limit } \\
\text { to the possibility of a fuller, greater state of being } \\
\text { individually or collectively }\end{array}$ & $\begin{array}{l}\text { There is no limit to the expansion and realisation of individual } \\
\text { potential expressed by ordinary people nor to achievement of a fuller, } \\
\text { greater, individual and collective state of being }\end{array}$ \\
\hline $\begin{array}{l}\text { Successful outcomes are dependent on the will and direction } \\
\text { of leaders }\end{array}$ & $\begin{array}{l}\text { Successful outcomes can be achieved independently of the will and } \\
\text { direction of leaders through the collective individual power of } \\
\text { ordinary individuals }\end{array}$ \\
\hline Think from the head & $\begin{array}{l}\text { Think from the heart, think into the being of another, including } \\
\text { human and non-human beings }\end{array}$ \\
\hline $\begin{array}{l}\text { Hopelessness and lack of awareness ensure continuation of } \\
\text { current climate change trajectory with all its terrifying } \\
\text { implications }\end{array}$ & $\begin{array}{l}\text { The ability to envisage a new world or possible world - a better place } \\
\text { where life interacts with itself and all around it in a completely } \\
\text { different way. Through hope, awareness and compassion, a world yet } \\
\text { to be born, frees the human spirit to its task and sets in motion a } \\
\text { power sufficient to remake the future }\end{array}$ \\
\hline
\end{tabular}

The new ethics model suggested above focuses on the power and potential of the individual, without any government or policy intervention, to decarbonise cities, regions and the world through eating less meat. There are none-the-less a number of policy pathways that could be recommended in support including:

- One day a week free of meat: Prominent individuals, e.g. Nobel Peace Prize winner and chair of IPCC Dr Pachauri, have called for this to reduce anthropogenic climate change, improve human health and animal welfare. The city councils of Cape Town (South Africa), Sao Paulo (Brazil), Bremen (Germany), Mechelen, Ghent and Hasselt (Belgium) have officially endorsed one meat free day a week. Others can do the same.

- Nutritional recommendations: Government-based nutritional recommendations could encourage people to eat more plant based protein sources, less meat and in general, could promote foods that are healthier, have a lower environmental impact, are more efficient in resource use and are more equitable.

- Public health funds incentives: Vegetarians/vegans are significantly less likely to suffer from the numerous diseases associated with excessive meat consumption and are thus less likely to be a drain on healthcare systems. Accordingly, like car or household insurance bonuses or incentives geared towards attracting those less likely to make big claims, public health funds could offer a sliding scale of bonuses and incentives to vegetarian or vegan members. Whilst this might be difficult to police, it will send a powerful messages to all. - Financial incentives for promotion of alternatives: Financial incentives (such as tax concessions, savings, superfund incentives etc.) could be given to industries and marketing companies promoting meat and dairy substitutes and plant-based alternatives. Personal tax and superfund incentives could also be provided to individuals choosing a more vegetarian/vegan diet (again this is difficult to police but not impossible).

- Education campaigns: Local and national councils could run campaigns similar to anti-cancer or antitobacco campaigns. Individual political representatives in appropriate constituencies (such as the outspoken City of Fremantle in Western Australia) could be supported by their political parties to show leadership by running education campaigns about the dangers of excessive meat consumption.

- Internalising the externalities: Local and national governments could insist on full cost pricing of livestock production. At the very least, meat should be taxed commensurate with its environmental and social production and consumption impacts and current subsidies to livestock production could be phased out. 
Given the wide range of vested interests, many of the above policies will be met by a strong opposition. Individual politicians, industry and community leaders can make calls for a change; however the possibility for each individual to be part of this transformation is the most powerful shift in ethics.

\section{CONCLUSION}

It is through choice that the power of the individual comes into play. Every person can make a difference because we all eat as sons, daughters, moms, dads, families, communities, generations, nations and increasingly as a globe. Eating is a social act and when we lift our forks, we set ourselves in one relationship or another, to farmed animals, national economies, global markets, environments and ultimately to politics. We can't stop our eating from radiating influence and impact even if we wanted to (Safran Foer, 2009). The food choices we make directly or indirectly impact countless others around us, and in so doing, determine our individual and collective future. The question of eating animals resonates deeply within those around you. As Australian-American actress Portia De Rossi recently commented: "people feel more uncomfortable with a vegan at their dinner table than they do a lesbian. It's confronting. It's kind of suggesting that what someone else is doing is bad or wrong and it hits them on a more personal level" (cited in VegNews, 2011).

Whether these resonances are controversial, threatening or inspiring, they are always filled with meaning. Such meaning, when aired publically, releases unexpected forces into the world (Safran Foer, 2009). Deciding to eat like everyone else adds another straw to the camel's back, an act which may not be a back breaker in itself but which will be repeated every day of our lives, and perhaps every day in the lives of our children and children's children. However it doesn't have to be this way. Even one day a week of different choices can make a significant difference and the best reason to know that there could be a better future is the fact that we know just how bad the future could be. We are each capable of changing the world and creating tremendous momentum: Ghandi - become the change you want to see in the world (unknown), Margaret Mead - never believe that a few caring people can't change the world; indeed, that's all who ever have (1928). If ordinary people are doing it on an increasing scale, vegetarian heads of state, legislators, business executives and global leaders and decision makers will quickly materialise (Goodland, 2010b).

Conversely those choosing to continue to eat excessive quantities of meat are accomplices in the maintenance of poverty, inequity, injustice, environmental destruction, the perpetuation of ongoing suffering and genocide of billions of sentient beings. Perhaps, one day such individuals will be judged or held accountable for wittingly participating in such crimes against humanity and the environment. Factory farming is only able to exist because of the relationships between industry, economics, politics and our insatiable demand for meat. Just as individual consumers have allowed for it to exist, by choosing to negate the power of vested interests, become informed, aware, compassionate, connected, engaged and influential change agents, we can weaken their existence. We can protect the planet, reclaim hope, facilitate the emergence of a world of kindness, equity and justice allowing the environmental to return to its natural functioning.

This requires an honest look, individually and collectively, at who we are, what we are doing and where this is taking us. Each of us needs to find the personal courage and strength to make the right choices for our own personal wellbeing and to take an individual stand, rally and unite with others against all forms of meatrelated exploitation, devaluation and the devastation of humanity, animals and nature. And here-in, within the power of the individual, lies the greatest opportunity for decarbonising our cities, regions and planet.

\section{REFERENCES}

Appleby, P.N., M. Thorogood, J.I. Mann, and T.J.A. Key (1999). The Oxford vegetarian study: An overview. The American Journal of Clinical Nutrition. 70, 525S-531S.

Australian Bureau of Statistics (ABS) (2009). Water Account, Australia, 2008-09, Cat. No. 4610.0. Canberra.

Coetzee, J. M. (1999). The Lives of Animals, Princeton University Press, Princeton.

Coetzee, J.M. (2007). A word from J.M. Coetze - Voiceless: I feel therefore I am, www.voiceless.org.au/About_Us/Misc/A_word_from_J.M._Coetzee_Voiceless_I_feel_therefore_I_am.

Campbell, T.C, and T.M. Campbell (2006). The China Study. Benbella Books, Dallas.

ChartsBin (n.d), Current Worldwide Annual Meat Consumption Per Capita, http://chartsbin.com/view/bhy.

Climate Institute (2011). A Climate of Suffering: The real cost of living with inaction on climate change. The Climate Institute, Melbourne and Sydney.

Compassion in World Farming (2004). Global Benefits of Eating Less Meat. Compassion in World Farming Trust, Hampshire.

Convention of Biological Diversity (CBD) (2010). Global biodiversity outlook 3. http://www.cbd.int/gbo/gbo3/doc/GBO3-final-en.pdf. 
Corvalan, C., S. Hales et al. (2005). Ecosystems and Human Well-Being: Health Synthesis, Millennium Ecosystem Report. WHO www.millenniumassessment.org/documents/document.357.aspx.pdf.

Department of Environmental, Food and Rural Affairs (DEFRA) (n.d). http://www.defra.gov.uk.

Dixon, J., A.M. Omwega, S. Friel, C. Burns, K. Donati, and R. Carlisle (2010). The health equity dimensions of urban food systems. Journal of Urban Health. 84(1S), 118-129.

Food and Agriculture Organisation (FAO) (2006). Livestock's Long Shadow. FAO, Rome.

Food and Agricultural Organisation (FAO) (2009). Global food supply gradually steadying but shocks could still be in store. http:/www.fao.org/news/story/en/item/20351/icode/.

Food and Agricultural Organisation (FAO) (2009a). The State of Food and Agriculture 2009: Livestock in the Balance. FAO, Rome.

Food and Agricultural Organisation (FAO) (2011) Livestock's role in deforestation, http://www.fao.org/agriculture/lead/themes0/deforestation/en/.

Gilligan, J., T. Dietz, G.T. Gardner, P.C. Stern, and M.P. Vandenbergh (2010). The behavioural wedge: Reducing greenhouse gas by individuals and households Significance, 7(1), 17-20.

Goodland, R., (2010a). How the Food Industry can reverse climate change quickly and profitably, presentation at the Global Forum for Food and Agriculture. International Green Week, Berlin.

Goodland, R (2010b). Law, Ethics, and the Livestock-Climate Connection, speech presented at the 18th Annual Animal Law Conference, Lewis and Clark Law School, Portland, Oregon.

Goodland, R., and J. Anhang (2009). Livestock and Climate Change. World Watch Institute. www.worldwatch.org/ww/livestock.

Hamerschlag, K. (2011). Meat Eater's Guide to Climate Change + Health. Environmental Working Group. http://www.ewg.org/meateatersguide/.

Hegarty, R. (2001). Greenhouse Gas Emissions from the Australian Livestock Sector: What Do We Know, What Can We Do? Australian Greenhouse Office, Canberra.

Intergovernmental Panel on Climate Change (IPCC) (2007). Climate Change 2007: The Physical Science Basis, Contribution of Working Group I to the Fourth Assessment Report of the Intergovernmental Panel on Climate Change. Cambridge University Press, Cambridge.

Mead, M. (1928). Coming of Age in Samoa. Morrow, New York.

Millston, E.,, and T. Lang (2003). The Atlas of Food. Earthscan, London.

Monday, E.A. (1999). Will we still eat meat? Time Magazine, http://www.time.com/time/magazine/article/0,9171,992523,00.html .

Parry, M.L., O.F. Canziani,. J.P. Palutikof, P.J. van der Linden, and C.E. Hanson (eds) (2007). Contribution of Working Group II to the Fourth Assessment Report of the Intergovernmental Panel on Climate Change, 2007, Cambridge University Press, Cambridge, United Kingdom and New York, NY, USA

Popkin, B. M. (2001). The nutrition transition and obesity in the developing world. Journal of. Nutrition. 131(3): 871S-873S.

Popkin, B.M. (2009). Reducing meat consumption has multiple benefits for the world's health. Archives of Internal Medicine. 169(6): 543-545.

Safran Foer, J. (2009). Eating Animals. Penguin Books, London.

Shaw, W.H. (1999). Contemporary Ethics: Taking Account of Utilitarianism. Blackwell, Oxford.

Simon, M. (n.d.). The Politics of Meat and Dairy, http://home.iae.nl/users/lightnet/health/meatpolitics.htm.

Singer, P. (1990). Animal Liberation, $2^{\text {nd }}$ edition. Harper Perennial, New York.

Singer, P., and J. Mason (2006). The Ethics of What We Eat. The Text Publishing Company, Melbourne.

Schneider, S. (2009). The Worst-case scenario. Nature, 458, 1104-1105, doi:10.1038/4581104a.

Stallworthy, M., (2009). Environmental justice imperatives for an era of climate change. Journal of Law and Society. 36(1), 55-74.

Stamoulis K, P. Pingali, and P. Shetty (2004). Emerging challenges for food and nutrition policy in developing countries. Electronic Journal of Agricultural and Development Economics. 1(2), 154-167.

Stern, N. (2006). Stern Review on the Economics of Climate Change. HM Treasury, London.

Stone, G. (Ed). (2011). Forks over Knives: The Plant-based Way to Health. The Experiment, New York.

Sutcliffe, B. (2007). Postscript to the article 'World inequality and globalization', Oxford Review of Economic Policy. http://siteresources.worldbank.org/INTDECINEQ/Resources/PSBSutcliffe.pdf .

US Census Bureau (2011). International Programmes: International Data Base and World Population. http://www.census.gov/population/international/data/idb/informationGateway.php.

VegNews (2011). De Rossi, P. http://vegetarianstar.com/2011/07/07/portia-de-rossi-on-vegnews-julyaugust2011-issue/. 